\title{
The China-Canada BIT, Its Shortcomings, and the Risks for Chinese Investors
}

\author{
Timothy S. McNamara \\ China University of Political Science and Law (CUPL), Beijing, China \\ Email: mcnamara.ts@gmail.com
}

How to cite this paper: McNamara, T. S. (2019). The China-Canada BIT, Its Shortcomings, and the Risks for Chinese Investors. Beijing Law Review, 10, 287-301. https://doi.org/10.4236/blr.2019.102018

Received: December 15, 2018

Accepted: March 22, 2019

Published: March 25, 2019

Copyright $\odot 2019$ by author(s) and Scientific Research Publishing Inc. This work is licensed under the Creative Commons Attribution International License (CC BY 4.0).

http://creativecommons.org/licenses/by/4.0/

\begin{abstract}
Given the pre-existing political constraints and the inadequacy of legal tools, some risks, such as inflation, are difficult for the BIT to insure against. Other risks, such as those stemming from changing demographics, may be even less understood or are difficult to discuss. Yet, as the nationalisations of white-owned farmland in Africa remind us, Chinese property investors in Canada need to understand not only the safety mechanisms contained in the BIT but also the longer-term demographic, political and cultural trends which will shape the investment landscape. Ultimately, if demographics are destiny, then Canada shows many features which suggest it is slowly evolving into a new South Africa. This essay explores some of the seldom discussed risks associated with investing in Canada.
\end{abstract}

\section{Keywords}

China-Canada BIT, Risks, Investment Treaty Shortcomings

\section{Introduction}

Although vast academic literature has been devoted to the concept of risk management and analysis, it is sometimes alleged that even investment professionals fail to understand or evaluate it properly. Both Nassim Taleb's Black Swan theory and behavioural finance provide us with some key insights into the harder to quantify risks. Against this background, at least for such non-lawyers, the logic underlying legal tools and concepts such as "foreseeability" and the "reasonable man" test often appear circular or unconvincing.

The purpose of this Note is to explore some of the real and often under-recognised risks which Canadian governments may actively or evenly passively pose for Chinese investors. As such, it neither seeks to promote China-Canada trade and investment nor to discourage it. Instead, the goal is simply to promote knowledge and discussion so that investors, policy professionals and the legal 
profession can better understand the need for comprehensive investor protection. The Note has three parts. First, it provides an overview of some demographic trends and the contours of the political culture as they affect the investment landscape in Canada and a discussion of the functionality of the China-Canada BIT, ${ }^{1}$ in that context, in protecting Chinese investors. Second, it examines key terms in the new BIT [commonly referred to as the Foreign Investment Promotion and Protection Agreement (China-Canada FIPA) ${ }^{2}$ ] to assess more concretely the proffered protections for Chinese investors. Finally, the paper concludes with a general discussion of how such treaties can fail to protect investors.

\section{Over-Arching Concerns and the Investment Landscape}

Expropriation does not necessarily imply a transfer of legal title.... it is difficult to draw a clear line between general regulations, which the investor must suffer, and expropriatory regulations, which must be accompanied by compensation. ${ }^{3}$

Rainer Geiger

\subsection{Background: Canada's Historical Development}

The central-eastern areas of Canada now known as Quebec, New Brunswick and eastern Ontario, hereinafter "French Canada," were first settled by the French in the $17^{\text {th }}$ and $18^{\text {th }}$ centuries with the first permanent settlements being in Port Royal-now known as Montreal-(in 1605) and Quebec City (in 1608). They were soon followed by the British who settled in surrounding areas, a trend which accelerated after French defeats to the British, as witnessed by the Treaty of Utrecht (1713) and the Seven Years' War (1763). This early history is somewhat complicated as, among the local Indian (native) ${ }^{4}$ tribes, the French and British had some natural allies and enemies, based on territorial claims. Nonetheless, there was also some shifting in alliances as both the British and the French attempted to entice, through incentives, the Indian tribes to wage war on the rival European power. As settlements increased and the military aspect of the conflict became less pronounced, it appears that Indians who married French Canadians in Quebec were essentially absorbed into one of the two communities while those who did so in Manitoba and Northern Ontario were often rejected by both, leading to the creation of Metis status. ${ }^{5}$

${ }^{1}$ Officially known as the China-Canada Foreign Investment Promotion and Protection Agreement (CCFIPPA).

${ }^{2}$ China and Canada signed a Bilateral Investment Treaty (BIT) on September 9th, 2012 entering into force on October 1st, 2014.

${ }^{3}$ Rainer Geiger, Regulatory Expropriations in International Law: Lessons from Multilateral Agreement on Investment, 11 N.Y.U. Envtl L. J. (2002): 100.

${ }^{4}$ Unless otherwise stated, throughout this paper I will use the terms "Indian", "native", "Aboriginal", "First Nations", and "First Peoples" interchangeably.

${ }^{5}$ Canada has approximately 700,000 status Indians, 200,000 non-status Indians and 300,000 Metis. See Peter W Hogg, Constitutional Law of Canada, 2011 Student Edition, at p. 28-3 and p. 28-4 (2011). 
The vast majority of Canadian land is now held by the Crown i.e. the federal or provincial government. ${ }^{6}$ In eastern Canada, territorial claims by the Native tribes are largely settled although disputes continue to arise over the rights of reservation Indians and Indians living off the reservation e.g. tax/no tax obligations. In contrast, in western Canada, particularly in British Columbia, the British government generally failed to sign treaties with the local Indian tribes and therefore much of the currently occupied territory including, perhaps, all of Vancouver is open to dispute as unlawfully occupied Native lands (Hogg, 2011: pp. 28-35). ${ }^{7}$ Therefore, before considering the China-Canada Bilateral Investment Treaty (BIT), we need first to understand the situation with regards to Canadian domestic law and the larger political trends.

\subsection{Risk \#1: Indian Land Claims and the Pipelines}

The underlying issues raised with respect to attempts by native Canadians to recover land and rights beyond those enshrined in the Indian Act are, it is submitted, akin in many respects to those attempts by older cultures to recover their overseas lost cultural property. In the near term, a Chinese businessman or land purchaser in Canada appears relatively secure in his title. But, then again, it is often said that "demographics is destiny": whites in Rhodesia in the 1950s and Palestinians in British Palestine in the 1930s no doubt also believed their tenure was secure. ${ }^{8}$ In the Canadian context, albeit from a relatively low base, the Aboriginal population grew from $1.2 \%$ of the overall Canadian population in 1961 (Saku, 1999) $)^{9}$ to $4.9 \%$ in the most recent survey ${ }^{10}$. Recent trends suggest that while the non-Aboriginal population born in Canada continues to stagnate, and the immigrant population is growing more slowly ${ }^{11}$, the Aboriginal population is younger, more fertile, and continues to grow by over $40 \%$ every 10 years $^{12}$. It is suggested that these population trends will have an important role to play in ${ }^{6}$ Approximately 89 percent of Canada's land area is Crown Land owned by federal (41 percent) or provincial (48 percent) governments; the remaining 11 percent is privately owned. See https://www.state.gov/e/eb/rls/othr/ics/2015/241511.htm (accessed Dec 3, 2018).

${ }^{7}$ Peter W Hogg, pp. 28-35.

${ }^{8}$ See also the situation in South Africa.

https://www.dailymail.co.uk/news/article-6446421/White-farmers-legal-fight-stop-land-given-black -South-Africans-without-compensation-thrown-out.html (accessed Dec 3, 2018).

${ }_{9}^{9}$ James C Saku, Aboriginal Census Data in Canada: A Research Note, The Canadian Journal of Native Studies, XIX 2 (1999) 365-379 at 370.

${ }^{10}$ https://www12.statcan.gc.ca/census-recensement/2016/as-sa/fogs-spg/Facts-CAN-eng.cfm?Lang=E $\underline{\text { ng\&GK}=\mathrm{CAN} \& \mathrm{GC}=01 \& \mathrm{TOPIC}=9}$ (accessed Dec 28, 2018).

${ }^{11}$ See archived content https://www150.statcan.gc.ca/n1/pub/91-003-x/2007001/4129907-eng.htm (accessed Dec 28, 2018).

${ }^{12}$ In recent years Statistics Canada appears to have consistently underestimated the growth of the Aboriginal population. For example, in this archived material we can see an estimated total of $4 \%$ by 2017. In fact, by 2016 the actual figure was $4.9 \%$

https://www150.statcan.gc.ca/n1/pub/89-645-x/2010001/growth-pop-croissance-eng.htm (accessed Dec 28, 2018). Note, however, that this growth has not been entirely organic or easily predicted: the lessening of stigma associated with Indian Status, a desire to access the economic and lifestyle benefits associated with Indian Status (e.g. free health care, affirmative action, tax exemptions and hunting rights) and court rulings on who is entitled to Indian Status appear to have all contributed to the category's growth. 
shaping Canadian laws and policy. ${ }^{13}$

The issue of Indian land claims may appear "off the radar" for most Chinese but it has major implications for the viability of Chinese investments in Canadian oil and gas. Indian land claims have complicated pipeline construction since at least the 1970s but in November, 2016 the Trudeau government finally decided to approve 2 pipelines (Kinder Morgan's Trans Mountain Expansion and Enbridge's Line 3) while rejecting the third (Enbridge's Northern Gateway).${ }^{14}$ Although it is fairly well established that lack of access to foreign markets is depressing the price of crude in North America, and in Canada in particular, the losses associated with a lack of pipelines appear to be too remote for a plaintiff to successfully establish a cause of action. Stated slightly differently, one does not have a "right" to build a pipeline on Indian lands. At the time of writing, no Chinese entity appears to have brought a claim for losses suffered as a result of the Northern Gateway decision. However, the losses these investors have suffered are undoubtedly severe. ${ }^{15}$ In any case, due to legal setbacks it is highly possible that none of these pipelines will be built ${ }^{16}$ and Canadian case law suggests the connection between the BIT and the land claims may be too remote ${ }^{17}$ for Chinese investors to receive compensation.

\subsection{Risk \#2: Indian Land Claims and Local Land Law}

In analysing Indian and other land claims, it is important to bear in mind an important difference between (English) common law and (Germanic) civil law rights. In essence, civil law land rights appear to be stronger and in a civil law context, such as Germany, one can speak of a private land "absolute owner". In the English (and Canadian) context this is not precisely true: although freehold owners and leasehold owners exist, along with other rights holders such as life estates or rights of way, ultimately all the land is owned by the Crown either outright or in its derivative form. ${ }^{18}$ For example, if someone in Canada dies without known relatives, his land would automatically revert to the Crown.

In western Canada, where the Indian land claims remain less settled, the Aboriginals generally live on Crown land. However, their claims often extend to developed areas, such as Vancouver, as well as competing with other natives who

\footnotetext{
${ }^{13}$ For example, since 1960, Status Indians have had the right to vote in Canadian federal elections. https://www.cbc.ca/news/canada/north/first-nations-right-to-vote-granted-50-years-ago-1.899354 (accessed Dec 28, 2018).

${ }^{14}$ https://www.nationalobserver.com/2016/11/29/news/breaking-trudeau-approves-kinder-morgan-p ipeline-rejects-one-two-enbridge-projects.

15"Canadian crude has become the most discounted oil on the planet",

https://seekingalpha.com/news/3410708-record-low-canadian-crude-price-shows-oil-sands-best-day s-past (accessed Dec 3, 2018).

${ }^{16}$ For more on this, Canadian Pipeline Work Blocked-WSJ at https://uk.advfn.com/stock-market/nyse/kmi/share-news/canadian-pipeline-work-blocked-wsj/7817 0419 (accessed Dec 3, 2018).

${ }^{17}$ Hupacasath First Nation $v$ the Minister of Foreign Affairs Canada and the Attorney General ot Canada 2015 FCA 4.

${ }^{18}$ The Crown has radical title or the allodium meaning that it is the ultimate owner of all land within its territory.
} 
also claim the same forested land. This situation is sometimes alleged as one of the reasons for the slow pace of land claims settlements: the government would have to choose among competing native groups as to which to give exclusive possession to when, as a historical fact, the competing tribes may have lived as nomads and shared the same piece of land.

Under these circumstances, Indians have rights not only to land but also to resources associated with those lands such as trees, fish, birds etc. Yet whether an Indian tribe would prevail in a court case, e.g. over timber, would generally depend on the history of that tribe and how it had interacted with those resources. ${ }^{19}$ As was the case with Risk \#2 above, Chinese litigating land investors would likely be hampered by the doctrine of remoteness.

\subsection{Risk \#3: The Dr. Zhivago Scenario}

The examples above dealt with risks to Chinese investors as posed by Indian claims. However, not all Canadian land claims come from Aboriginals. As we can see in the example of post-colonial Africa generally and South Africa today, majority rule and populist government often bring particular challenges for property owners. And as the Caucasian population in Canada shrinks in relative size and identity politics continue to gain traction, it is certainly possible that Caucasians will begin to behave more like typical North American minorities e.g. trying to advance their interests by confiscating or taxing the property of others.

How would this play out in practice? In the movie Doctor Zhivago, as a result of new Soviet policy, the main character is forced to admit many homeless people into his house so that these new (previously homeless) individuals are able to enjoy the benefit of his unused rooms. While Canada is not the Soviet Union, it is worth remembering that absentee foreign land owners are exposed to special risks. In general, they should inspect their property at least every seven years to ensure that no competing claimholders (i.e. squatters) are using their property and they should also be aware of the changing political climate and attitudes towards Chinese investors. For example, Australia has introduced a new land tax to discourage foreign buyers and New Zealand is in the process of blocking such purchasers. Meanwhile, in Canada, a Vancouver mayor has advocated a special $3 \%$ annual tax on non-resident land owners who refuse to rent out their empty properties. ${ }^{20}$ There does not appear to be anything in the current China-Canada BIT to protect investors against this assault on residential property rights.

\subsection{Risk \#4: Excessive Land Taxes}

While the prospect of Vancouver property owners being compelled to share

${ }^{19}$ Aboriginals (i.e. status Indians, Metis and Innuit) may also have usage rights e.g. hunting, fishing or harvesting on land for which they do not have aboriginal title. In contrast, aboriginal title is the right to exclusive occupation of the land. (See Peter W Hogg at p. 28-28). Generally, court cases initiated by British Columbia based tribes concern aboriginal rights rather than treaty rights.

${ }^{20}$ The new mayor was able to gain approval for a $1 \%$ per annum tax on certain residential properties. However, his stated goal remains 3\% https://www.lexology.com/library/detail.aspx?g=d35f92fe-ce7b-48fd-95cb-35000935829a （accessed Dec. 3, 2018). 
their houses with Vancouver's homeless may appear remote, the acute housing shortage there as well as the negative trends in Canada's overall fiscal situation suggest that some combination of spending cuts and/or tax increases may be unavoidable. As foreign landowners have no voting rights qua landowners, the risk of massive increases in land taxes should not be discounted. Although this may seem unfair, the abstract fairness argument has never been upheld by a Canadian court. Only arguments based on "mistake of fact" (e.g. error calculation) can expect to be upheld. Therefore, the current BIT appears to be of limited value to Chinese investors here.

\subsection{Risk \#5: Excessive Sector Taxes}

A populist demand in Canada has been that "companies", especially "big companies", should pay more taxes. Although many economists argue instead for greater analytical specificity i.e. that "company" tax be broken down into either capital gains or dividends and taxed only on shareholder receipt, local populist impulses cannot be discounted. At various times, Canadian politicians have targeted particular industries which were out of favour. This happened most recently in Alberta, which witnessed a "modernized" resource royalty regime as instituted by a new government that had promised higher taxes. ${ }^{21}$ However, unless such tax changes are designed in a de facto sense to penalise foreigners, it is an open question whether they would constitute an indirect expropriation even under customary international law. ${ }^{22}$ In this sense, the concept of "excessive" tax can also be difficult to establish and the BIT is unlikely to come to the rescue.

\subsection{Risk \#6: Excessive Regulations}

Regulations may have the same indirect expropriatory effect as taxes if they target a particular industry or company. For instance, if a particular industry is exposed to regulations that serve no apparent public policy purpose but have the de facto effect of favouring one firm over another, it might be argued that the losses suffered by the aggrieved firm should be attributable to the state. ${ }^{23}$ In other cases a "legitimate" public purpose may be served but the burden will not always fall evenly on all firms in the industry. For example, in the context of Alberta, a new carbon tax was introduced as part of the government's commitment to green energy. However, some oil producers argued that the assessments did not apply fairly and older wells were more heavily penalized than newer wells. Although there has been some litigation on this point, so far there do not appear

\footnotetext{
${ }^{21}$ http://calgaryherald.com/business/energy/live-notley-unveils-royalty-review-report (accessed Dec $3,2018)$.

${ }^{22}$ Note that, in a European context, the ECHR has consistently held that differences in treatment do not constitute discrimination if they have an "objective and reasonable justification": Fabri p. 172.

${ }^{23}$ Some authors prefer the term "deprivation" to expropriation as it can encompass both formal and de facto expropriation. See Helene Ruiz Fabri, The Approach Taken by the European Court of Human Rights to the Assessment of Compensation for Regulatory Expropriations of the Property of Foreign Investors, 11 N.Y.U. Envtl L.J. 148 (2002): 155.
} 
to be any China-related plaintiffs. And none of the litigants to date have succeeded.

\subsection{Investment Canada}

Canada's attitude towards foreign direct investment (FDI) has often been rather ambivalent. After much public debate in the 1950s and 1960s, Prime Minister Pierre Trudeau created the Foreign Investment Review Agency (FIRA) in 1972 with the express purpose of limiting foreign ownership of the Canadian economy. This was done against the backdrop of nationalisations around the world and strong anti-American sentiments in Canada. However, in 1985 Prime Minister Mulroney renamed FIRA as "Investment Canada" and greatly reduced its mandate. Under the new mandate, foreign investments would continue to be subject to review but the test is now whether there is a "net benefit" to Canada. Although this formulation suggests the presumption remains against foreign investment, as the foreign investor must first prove the benefit before making the investment, in fact it appears that the threshold to be met is rather low and, thus, even a small benefit, such as maintaining employment in a shrinking market, might be sufficient to meet the threshold.

One of the significant features of Investment Canada is that, in the current context, it appears that only foreign investments which are granted approval will be able to rely on the provisions of the FIPA. ${ }^{24}$ (This is in contrast to some Multilateral Agreements on Investment (MAI) proposals under which recourse to arbitration would be open to investors not only after the investments were established but even at the pre-establishment phase.) (Geiger, 2002) ${ }^{25}$ Unlike Australia, which provides a transparent list of factors that it takes into account, Canada's approach is "subjective, opaque and interventionist" and puts the onus on foreign investors to explain why their investments should be allowed (Dobson, 2014). ${ }^{26}$

\section{Examining Key Terms in the China-Canada BIT}

... investment agreements between a host state and a foreign corporation are, in principle, founded in the national law of the host state, rather than in an undefined international legal order. ${ }^{27}$

Rudolf Dolzer

\subsection{China-Canada FIPA (CCFIPPA)}

China and Canada have a long history of relatively good relations. For example, when China began developing closer political and economic ties with the Soviet

${ }^{24}$ In other words, under the current arrangement, if denied approval to invest, the Chinese investor would be pre-emptively excluded from access to the BIT mechanisms.

${ }^{25}$ Rainer Geiger, Regulatory Expropriations in International Law: Lessons from Multilateral Agreement on Investment, 11 N.Y.U. Envtl L. J. (2002): 101.

${ }^{26}$ Wendy Dobson, “China's State-Owned Enterprises and Canada's FDI Policy," The School of Public Policy Research Paper Series 7 (10) (March 2014): 20.

${ }^{27}$ Rudolf Dolzer, Indirect Expectations: New Developments, 11 N.Y.U. Envtl L. J. 64, (2002): 67. 
Union, the US retaliated and, along with six allies in Europe (the UK, France, Italy, the Netherlands, Luxemburg and Belgium), imposed trade controls and restrictions in relation to China (Ho \& Huenemann, 1972: p. 19). ${ }^{28}$ Canada was never part of that group (Ho \& Huenemann, 1972: p. 21).$^{29}$ Later, in 1970, Canada became one of the first Western countries to recognise the People's Republic of China.

Today, the Chinese and Canadian economies are highly complimentary: Canada has natural resources while China has human resources and manufacturing. The FIPA has 5 key articles which may be able to protect Chinese investors. We shall examine each in turn.

\subsection{Article 4-Minimum Standard of Treatment}

The minimum standard of treatment is the "fair and equitable treatment" and "full protection and security" standard as set out in international law.

In the Canadian context, customary international law will provide a guide to interpreting Canadian BITs before arbitration tribunals. Thus, FIPA will be influenced, inter alia, by past decisions of the European Court of Human Rights (ECrtHR), NAFTA panels and the Iran-United States Claims Tribunal. Therefore, we shall discuss FIPA articles in conjunction with customary international law.

It is a well-recognised rule under international law that the government cannot expropriate the property of aliens without adequate compensation. ${ }^{30}$ The "Hull formula" states that such compensation should be "prompt, adequate and effective." 31 "Prompt" compensation means payment must occur at the time of the taking or include interest from the time of the taking until payment. "Adequate" means fair market value for the property taken. And "effective" means funds are paid in an international currency or freely exchangeable into such currency and eligible for repatriation (Merrill, 2002: p. 112). ${ }^{32}$

If the ECHR is viewed as regional law rather than international law, then one of the most import sources of customary law becomes the Iran-United States Claims Tribunal. The tribunal has set out its own conditions for a lawful expropriation: public purpose, non-discrimination and compensation (Escarcena, 2013). ${ }^{33}$ Of course, while all expropriations are takings, not all takings are expropriations. The Iran-United States Claims Tribunal has held that in assessing the alleged deprivation, the intent of the government measure is less important than its effect (Dolzer, 2002: p. 87). ${ }^{34}$

\footnotetext{
${ }^{28}$ Samuel P.S. Ho and Ralph W, Huenemann, Canada's Trade with China: Patterns and Prospects (Quebec: Canadian Economic Policy Committee, June 1972), 19.

${ }^{29}$ Ho and Huenemann, Canada's Trade with China, 21.

${ }^{30}$ OECD (2004), "Indirect Expropriation" and the "Right to Regulate" in International Investment Law”, OECD Working Papers on International Investment, 2004/04, OECD Publishing, p. 2.

${ }^{31}$ OECD (2004) p. 2.

${ }^{32}$ Thomas W Merrill, p. 112.

${ }^{33}$ Sebastian Lopez Escarcena, Expropriations and other measures affecting property rights in the case of the Iran-United States claims tribunal, Wisconsin Law Journal, 12/12 (2013): 1.

${ }^{34}$ Rudolf Dolzer, p. 87.
} 


\subsection{Article 5-Most-Favoured-Nation (MFN) Treatment}

Article 5 of the FIPA offers Chinese investors in Canada most favoured nation status in regards to their investments in Canada. There seems to be some debate, however, as to whether these should be viewed as substantive rules or procedural protections. However, Article 5 appears to expressly exclude comparison with dispute resolution mechanisms in other treaties. ${ }^{35}$

With regards to arbitration tribunals, there have been frustrations in various jurisdictions, including the US, over "incorrect" decisions by courts and tribunals and in particular over who should have the final say to correct these errors. In Canada, the court, in theory, will not look into the merits of a tribunal's NAFTA decision. Moreover, panel decisions are persuasive but not binding on other panels. ${ }^{36}$

Understandably, this situation generated frustrations over the process, which led then-Senator John Kerry to criticize what he perceived as a circular concept of international law, and to attempt to rein in the power of the NAFTA tribunals. ${ }^{37}$ However, there are compelling arguments in favour of both court and tribunal-led processes. At the time of writing, NAFTA is subject to possible replacement by the USMCA, which could also affect future Chinese investments in Canada that would rely on NAFTA provisions for access to the American and Mexican markets.

In Canada, the MFN clause and the power of the arbitration tribunals have also been criticized by the political left, notably in relation to NAFTA in the early 1990s and, more recently, the China-Canada BIT. In particular, it is alleged that for the China-Canada BIT, the pre-establishment MFN, in combination with a lack of pre-establishment National Treatment and Canada's other BITs have created a non-reciprocal relationship between Canada and China (in China's favour).$^{38}$ This would be both de jure and de facto because of the more generous BITs Canada previously entered into with other countries and the more open nature of the Canadian economy (Van Harten, 2014). ${ }^{39}$ It is submitted, however, that such reasoning is rather shallow as it presupposes: 1) Chinese investors would not be able to access such benefits anyways, albeit by incorporating or investing from the third country in question, 2) that the Canadian gov-

${ }^{35}$ Art 5 (3) states: For greater certainty, the "treatment" referred to in paragraphs 1 and 2 of this Article does not encompass the dispute resolution mechanisms, such as those in Part C, in other international investment treaties and other trade agreements.

${ }^{36}$ Roundatable Discussion on Domestic Challenges if Multilateral Investment Treaties are Interpreted to Expand the Compensation Requirement for Regulatory Expropriations beyond a Signatory State's Domestic Law, 11 N.Y.U. Envtl L. J. 208 (2002): 250.

${ }^{37}$ Roundtable Discussion, p. 246.

${ }^{38} \mathrm{See} \mathrm{http://www.fipafacts.ca/} \mathrm{and} \mathrm{Gus} \mathrm{Van} \mathrm{Harten,} \mathrm{The} \mathrm{Canada-China} \mathrm{FIPPA:} \mathrm{Its} \mathrm{uniqueness} \mathrm{and}$ non-reciprocity, Canadian Yearbook of International Law (2014).

${ }^{39}$ Gus Van Harten, The Canada-China FIPPA: Its uniqueness and non-reciprocity, Canadian Yearbook of international Law (2014). It is submitted, however, that such an analysis really misses the point: a BIT or even a unilateral declaration may benefit the capital importing country even more than the capital exporting since the guarantee can effectively push down the cost of capital (as risk in the destination is perceived as being lowered). A low cost of capital is associated with higher wages, economic growth and a higher standard of living. 
ernment was uncomfortable with offering such guarantees to the third countries, and /or 3) that the BIT limits the government's policy options rather than freeing it, in a politically expedient manner, from possible policy mistakes, the pressure of domestic special interest groups, and outdated regulations.

\subsection{Article 6-National Treatment}

Under the FIPA, each Contracting Party (i.e. China and Canada) accords to investors of the other Contracting Party no less favourable treatment than it accords its own investors in regards to the management, conduct, operation and sale or other disposition of investments in its territory.

We can look to NAFTA as an example of how this may work in practice. In determining the National Treatment standard, the NAFTA Tribunal held that the correct test is: "whether the practical effect of the measure is to create a disproportionate benefit for nationals over non-nationals[sic]; whether the measure, on its face, appears to favour its nationals over non-nationals who are protected by the relevant treaty" (Dolzer, 2002, p. 84). ${ }^{40}$

\subsection{Article 10-Expropriation}

The investments covered by the FIPA are not to be expropriated, nationalized, or subject to measures having equivalent effect except pursuant to a public purpose and under domestic due process procedures in a non-discriminatory manner. Should the investment be thus expropriated, the investor would also be entitled to compensation at the fair market value before the expropriation occurred or became public knowledge, whichever is earlier.

Naturally, this raises many questions. For example, is the "public purpose" concept open to substantive examination or must it be accepted that anything passed by the legislature is a "public purpose"? Would a program of dubious merit, e.g. a Nazi-style affirmative action program, get a pass or would the Tribunal look into the merits of the "public purpose"? The general view is that liability does not arise from actions that are non-discriminatory and within the commonly accepted police and taxation powers of the state (Aldrich, 1994). ${ }^{41}$

Since NAFTA, it has been recognised that foreign investors often have a higher degree of protection for their property rights than nationals do. ${ }^{42}$ But was this imposed by the panels or was this part of the original intent behind the ambiguous statutory language? There is uncertainty on this point, due to the ambiguous language used in the NAFTA provisions. ${ }^{43}$ However, the US government position on international law and expropriation is in conformity with the 
US takings doctrine and it may be that the American view has become an international norm. ${ }^{4}$

\subsection{Article 11-Compensation for Losses}

Article 11 of FIPA promises Chinese investors that they will be able to sue the Canadian government for compensation in the event Chinese firms in Canada suffer losses due to "war, state of national emergency, insurrection, riot or other similar event". Mukesh Khanal argues that "emergency" is the most likely scenario in Canada and could include a natural one such as flooding, ice storm, power blackout or SARS epidemic. ${ }^{45}$ However, the value of such protection is questioned by some analysts, who argue, for example, that the Japan-China FIPA did not result in adequate compensation for the Japanese businesses targeted in the 2012 Chinese mob attacks. ${ }^{46}$ Other legal doctrines, such as foreseeability and remoteness, might also bar claims for losses from a massive devaluation of the Canadian dollar.

\section{General Issues Pertaining to BIT Agreements}

Though deprivations of property in the sense of confiscations will require compensation, the [European] Court has shown itself willing to permit controls of use without compensation in certain circumstances. ${ }^{47}$

Helen Mountfield

\subsection{Indirect Expropriation}

Indirect expropriation, through excessive regulations, temporary seizure or taxes, is a subtle mechanism which is both difficult to identify and to protect against. The line between indirect expropriation requiring compensation and normal governmental regulations not requiring such compensation has not been clearly drawn and depends on the facts of the situation. ${ }^{48}$ Hassan Sedigh states that the boundary between regulation and expropriation rests on the reasonableness of the interference (Sedigh, 2001). ${ }^{49} \mathrm{~A}$ mere diminution in value is not enough to constitute a taking/expropriation: it must be large enough. ${ }^{50}$

The China-Canada BIT adopts a reasonable, middle-of the road stance to the issue, both recognizing the concept of indirect expropriation while also acknowledging circumstances where such interference with the free market may be

\footnotetext{
${ }^{44}$ Roundtable Discussion, p. 222.

${ }^{45}$ Mukesh Khanal, Canada's FIPA with China, Master of Public Policy Capstone Project, The University of Calgary, pp. 29-30.

${ }^{46}$ Khanal p. 31. Also, see Micheal Den Tandt, "The little glitch ignored by FIPA enthusiasts is that China doesn't follow rules," National Post, November 16, 2012.

${ }^{47}$ Helen Mountfield, Regulatory Expropriations in Europe: The Approach of the European Court of Human Rights, 11 N.Y.U. Envtl L.J. 136 (2002): 142

${ }^{48}$ OECD (2004), p.3.

${ }^{49}$ Hassan Sedigh, What Level of Host State Interference Amounts to a Taking under Contemporary International Law, 2 J. World Investment 631 (2001):682.

${ }^{50}$ Roundtable p. 262
} 
necessary: ${ }^{51}$

1) Indirect expropriation results from a measure or series of measures of a Contracting Party that has an effect equivalent to direct expropriation without formal transfer of title or outright seizure.

2) ...

3) Except in rare circumstances, such as if a measure or series of measures is so severe in light of its purpose that it cannot be reasonably viewed as having been adopted and applied in good faith, a non-discriminatory measure or series of measures ... designed and applied to protect the legitimate public objectives for the well-being of citizens, such as health, safety and the environment, does not constitute indirect expropriation.

It has also been suggested that the phrase "tantamount to expropriation" refers not only to intentional or obvious indirect expropriation but should include inappropriate regulatory acts or omissions that undermine the framework of the BIT (Gutbrod et al. 2009).52 At this time no clear-cut test has emerged and the China-Canada BIT hedges on this question by calling for a "case-by-case, fact-based inquiry" ${ }^{\prime 3}$. It is also unclear if severity of impact on the investor is the sole or simply the predominant factor (or even one of many factors!) to be considered (Gutbrod et al. 2009: pp. 299-300) ${ }^{54}$ Finally, in the event of mala fide by the State, would it be a factor in finding an indirect expropriation? If so, what would mala fide look like in Canada, as opposed to Russia? ${ }^{55}$

In drawing the line between legitimate regulations and indirect expropriation, tribunals have focused on: 1) the degree of interference, 2) the character of the governmental measure and 3) whether the interference was reasonable and in conformity with investment-backed expectations. ${ }^{56}$

A transfer of title or even the "temporary" nature of an infringement is not necessarily the decisive issues. Instead, courts will look at various criteria to determine if there has been an expropriation. Some necessary (but not necessarily sufficient) factors that have been considered include: 1) severe economic impact (losing all or most of the property's economic value) ) $^{57}$ especially if permanent or irreversible ${ }^{58}$, 2) long durations (greater than 3 years) $)^{59}$, 3) the government

\footnotetext{
${ }^{51}$ Agreement Between the Government of Canada and the Government of the People's Republic or China for the Promotion and Reciprocal Protection of Investments, Canada and China, Annex B.10.

${ }^{52} \mathrm{Max}$ Gutbrod et al. Protection against Indirect Expropriation under National and International Legal Systems, Gottingen Journal of International Law 1, (2009): 297.

${ }^{53}$ Agreement Between the Government of Canada and the Government of the People's Republic o1 China for the Promotion and Reciprocal Protection of Investments, Canada and China, Annex B.10. ${ }^{54}$ Max Gutbrod et al. pp. 299-300.

${ }^{55}$ I have in mind a Yukos scenario in Russia, where the asset was seized on de jure grounds of tax evasion but what were widely reported in the media as simply de facto political transgressions. In the Canadian context, the closest near example I can think of would be the Black peerage case, which involved rather minor economic value and the alleged mala fide was found to be within the government's prerogative powers.

${ }^{56}$ OECD (2004), p. 22.

${ }^{57} \mathrm{OECD}$ (2004), p. 10.

${ }^{58}$ OECD (2004), p. 11.

${ }^{59} \mathrm{OECD}$ (2004), p. 14
} 
measure not being for a recognised social purpose ${ }^{60}$ and 4) the government action not being proportionate to the infringement. ${ }^{61}$

With regards to taxation/compensation the US test is whether the level of State compensation would shock the conscience (Weston, 1975). ${ }^{62}$ Thus, expectations play a role. For example, raising a tax from $75 \%$ to $85 \%$ might not be subject to the same conclusion as raising one from $10 \%$ to $80 \%$ (Dolzer, 2002: p. 78). ${ }^{63}$ Here, case law includes many German Jews or Jewish sympathisers who claimed they were forced to sell or voluntarily sold their European investments at excessively low prices pre-WWII, later alleging the pressure they were under constituted a de facto expropriation.

Under NAFTA, a rather generous approach was taken: "a significant degree of deprivation of fundamental rights of ownership" might be sufficient to find an expropriation..$^{64}$ Note, however, that under Chapter 11 of NAFTA if a taking "tantamount to" an expropriation of foreign property is incurred, compensation is limited to general damages i.e. the market value of the property taken (Merrill, 2002: p. 111). ${ }^{65}$

With regulatory takings we find no guidance on how to calculate investor values (Merrill, 2002: p. 115) ${ }^{66}$ If it is suggested that the State wishes to maintain ownership in private hands but to limit prices to consumers, an alternative pricing and incentives model is needed. One alternative from American law is the utility model, which compensates the investor at a market value for the asset with a fair return on investment standard (Merrill, 2002: p. 124). ${ }^{67}$

\subsection{Assessing Market Value}

It is now a standard feature of BITs to compensate the aggrieved foreign party "market value". But how does the FIPA approach compare to other jurisdictions? In the European context, the ECrtHR has stated that full value need not be paid but payment must not be "manifestly disproportionate" (Fabri, 2002: p. 166). ${ }^{68}$ Three methods have been used there: 1) The value of the shares or company assets over a period of time, 2) A hypothetical market value, or 3) A quoted market value (where available) for the shares over a reference period (Fabri, 2002: pp. 167-168). ${ }^{69}$ Given the wide "margin of appreciation" within which the States operate, the European Court has also allowed the States to avoid compensating for inflation or even the traditional "control premium" (Fabri, 2002: p. 169). ${ }^{70}$ Of course, it must be accepted that valuation is not a science per se, de-

${ }^{60} \mathrm{OECD}(2004)$, p. 16

${ }^{61}$ OECD (2004), p. 20.

${ }^{62}$ Burns H Weston, Constructive Takings under International Law: A Modest Foray into the Problem of Creeping Expropriation, 16 Va. J. Int'l L. 103 (1975): 146.

${ }^{63}$ Rudolf Dolzer p. 78.

${ }^{64}$ OECD (2004), p. 12.

${ }^{65}$ Thomas W Merrill, Incomplete Compensation for Takings, 11 N.Y.U. Envtl L.J. 110 (2002): 111.

${ }^{66}$ Thomas W Merrill, p. 115.

${ }^{67}$ Thomas W Merrill, p. 124.

${ }^{68}$ Fabri, p. 166.

${ }^{69}$ Fabri, pp. 167-168.

${ }^{70}$ Fabri, p. 169. 
spite its reliance on mathematics: valuation is really an art.

For a US expropriation of a company there are two methodologies: 1) a net book value approach which is backward-looking and based on asset prices and 2) a going concern approach which is forward-looking and based on future expected/projected discounted cash flows (Merrill, 2002: p. 114). ${ }^{71}$ For a profitable business, the going concern methodology would offer a higher valuation.

In the US, to cover the case of a "partial takings" (e.g. some but not all of the land on a property to build a road), a partial takings model was developed. It seeks to compensate the owner the fair market value for that which is taken and the loss due to the damage inflicted on what was not taken (Merrill, 2002: p. 121)..$^{72}$ In terms of payout, it is closer to an indemnification standard but has been condemned as it still does not cover attorney fees and lost goodwill and profits etc.

From the viewpoint of an investor, even the American model probably offers inadequate payment since the fair market value is lower than the owner's subjective value: he had wanted to keep the property! (Merrill, 2002: p. 119) ${ }^{73}$

\section{Conclusion}

This Note has examined some key demographic and political trends in Canada and used the China-Canada BIT as a rubric through which to analyse the piecemeal attempts by BITs to protect investors, in contrast to the more comprehensive or holistic protection such investors may desire.

Implied in the analysis was an assumption that such guarantees might not be cost-free and that each guaranteed benefit-whether to native Indians or foreign investors or others-would have a cost or risk consequence, at least at the systemic level. Further study is needed to determine whether this cost is being borne at the systemic level by Canada as a whole, by the non-protected elements within Canadian society, or by some combination of the two. Another necessary consequence of Canada's "shallow discussion" level has been the lack of legal insight into who would bear the sustainability costs in a crisis: would they be borne solely by unprotected groups (e.g. white men) or are the Canadian guarantees in fact breachable? And, if breached, how would the guarantees be prioritized?

As shown in the discussion, many legal mechanisms and doctrines, such as remoteness and national treatment, may limit or at least offer little practical benefit to the foreign investor in a rule of law country that seeks to preserve its reputation for fair dealing, such as Canada. Belying the importance of independent arbitration, it is suggested that such mechanisms and doctrines, taken to their extreme, might even offer legal avenues under which the government could renege on its debts. However, despite its shortcomings, the new China-Canada BIT does offer Chinese investors an additional mechanism to guarantee the security of their capital against extreme state behaviour. Of course, 
as with any other assurance, such a guarantee is only as credible as the party which issues it.

\section{Conflicts of Interest}

The author declares no conflicts of interest regarding the publication of this paper.

\section{References}

Aldrich, G. H. (1994). What Constitutes a Compensable Taking of Property? The Decisions of the Iran-United States Claims Tribunal. The American Journal of International Law, 88, 585-610. https://doi.org/10.2307/2204132

Dobson, W. (2014). China's State-Owned Enterprises and Canada's FDI Policy. The School of Public Policy Research Paper Series, 7. https://journalhosting.ucalgary.ca/index.php/sppp/article/view/42463

Dolzer, R. (2002). Indirect Expectations: New Developments. NYU Environmental Law Journal, 11, 64.

Escarcena, S. L. (2013). Expropriations and Other Measures Affecting Property Rights in the Case of the Iran-United States Claims Tribunal. Wisconsin Law Journal, 31, 177-207. https://hosted.law.wisc.edu/wordpress/wilj/files/2014/01/Escarcena_final_v2.pdf

Fabri, H. R. (2002). The Approach Taken by the European Court of Human Rights to the Assessment of Compensation for Regulatory Expropriations of the Property of Foreign Investors. NYU Environmental Law Journal, 11, 155.

https://www.nyuelj.org/issues/volume-11/

Geiger, R. (2002). Regulatory Expropriations in International Law: Lessons from Multilateral Agreement on Investment. NYU Environmental Law Journal, 11, 100. https://www.nyuelj.org/issues/volume-11/

Gutbrod, M. et al. (2009). Protection against Indirect Expropriation under National and International Legal Systems. Gottingen Journal of International Law, 1, 291.

Ho, S. P. S., \& Huenemann, R. W. (1972). Canada's Trade with China: Patterns and Prospects. Quebec: Canadian Economic Policy Committee.

Hogg, P. W. (2011). Constitutional Law of Canada (2011 Student Edition).

Merrill, T. W. (2002). Incomplete Compensation for Takings. NYU Environmental Law Journal, 11, 110. https://www.nyuelj.org/issues/volume-11/

Saku, J. C. (1999). Aboriginal Census Data in Canada: A Research Note. The Canadian Journal of Native Studies, XIX, 365-379.

Sedigh, H. (2001). What Level of Host State Interference Amounts to a Taking under Contemporary International Law. Journal of World Investment \& Trade, 2, 631. https://doi.org/10.1163/221190001X00013

Van Harten, G. (2014). The Canada-China FIPPA: Its Uniqueness and Non-Reciprocity. Canadian Yearbook of International Law.

Weston, B. H. (1975). Constructive Takings under International Law: A Modest Foray into the Problem of Creeping Expropriation. Virginia Journal of International Law, 16, 103.

https://www.worldcat.org/title/constructive-takings-under-international-law-a-modest -foray-into-the-problem-of-creeping-expropriation/oclc/769979643 